\title{
Viewpoint: The present status and future prospects of squirreltail research
}

\author{
T. A. JONES
}

Author is research geneticist, USDA-ARS Forage and Range Research Laboratory, Utah State University, Logan 84322-6300.

\begin{abstract}
Squirreltail's [Elymus elymoides (Raf.) Swezey = Sitanion hystrix (Nutt.) J.G. Smith] ready germination, rapid reproductive maturity, capacity for cool-temperature growth, self-pollinated mating system, excellent seed dispersal mechanisms, fire tolerance, and genetic diversity make it a promising candidate for assisting ecological restoration of rangelands dominated by exotic weedy annual grasses such as medusahead wildrye [Taeniatherum caput-medusae (L.) Nevski] and cheatgrass (Bromus tectorum L.). Squirreltail is a short-lived perennial and generally early seral in successional status. It comprises a complex of several subspecies whose ecological amplitudes are poorly understood. Wildfire or prescribed burning may provide opportunities for seeding squirreltail or augmenting existing populations. Grazing deferment is important for a successful transition from an annual to a perennial-dominated grassland. Reduction in frequency of annuals may facilitate natural or artificial establishment of desirable mid- or late-seral grasses, forbs, and shrubs. Currently, squirreltail seed supplies originate from wildland harvests. Reduced cost, dependable supply, and improved quality of seed will require development of efficient commercial seed production practices. Experience in restoration may reveal the suitability of squirreltail plant material for assisted succession as well as expose its weaknesses. Such information will allow researchers to improve plant materials and methods for increased future success.
\end{abstract}

Key Words: cheatgrass, Elymus elymoides, medusahead wildrye, rangeland fire, Sitanion hystrix

\section{Taxonomic Status}

While I refer to squirreltail as Elymus elymoides (Raf.) Swezey because of this grass' close phylogenetic relationship to other Elymus species, most readers are more familiar with the name Sitanion hystrix (Nutt.) J.G. Smith. Squirreltail was first described in 1818 by Nuttall as a species of Aegilops, placed in Elymus in 1824 by Schultes, and assigned the epithet elymoides in 1891 by Swezey (Wilson 1963). Eight years later it was renamed Sitanion hystrix, a name perpetuated by Hitchcock (1950). A disarticulating rachis and subulate glumes extending into long awns are characteristic of Sitanion.

Contribution of Utah Agr. Exp. Sta., Journal Paper 5040, and USDA-ARS Forage and Range Research Laboratory.

Manuscript accepted 21 Jun. 1997.
Wilson (1963) recognized Sitanion was not distinct from Elymus, but refrained from combining them. Based on their selfpollinating mode of reproduction, small anthers, caespitose growth habit, and allotetraploidy $(2 n=28)$, Barkworth et al. (1983) included S. hystrix and S. jubatum J.G. Smith in Elymus as $E$. elymoides and E. multisetus (J.G. Smith) Burtt-Davy, respectively. These species include genomes derived from Pseudoroegneria (St) and Hordeum (H) (Dewey 1974, Wang et al. 1996). This chromosome constitution has been confirmed by chromosome pairing data in hybrids of squirreltail with other species. For example, the single bluebunch wheatgrass [Pseudoroegneria spicata (Pursh) A. Löve] St genome may pair with the homologous genome of squirreltail (Dewey 1964) and the single Hordeum bogdanii Wilensky $\mathbf{H}$ genome (Dewey 1971). Both St and $\mathbf{H}$ genomes of squirreltail may pair with both genomes in hybrids with the tetraploid taxa thickspike wheatgrass [E. lanceolatus (Scribn. and J.G. Smith) Gould ssp. lanceolatus] (Dewey 1968), Montana wheatgrass [E. lanceolatus ssp. albicans (Scribn. and J.G. Smith) Barkw. and D.R. Dewey] (Dewey 1969), slender wheatgrass [E. trachycaulus (Link) Gould ex Shinners] (Boyle 1963), blue wildrye (E. glaucus Buckl.) (Stebbins and Vaarama 1954), and Canada wildrye (E. canadensis L.) (Dewey 1967) because, like squirreltail, they contain both St and $H$ genomes. Natural sterile hybrids between $S$. hystrix and tetraploid Basin wildrye [Leymus cinereus (Scribn. and Merr.) A. Löve] have been reported near Shoshone, Ida. (Dewey and Holmgren 1962). They exhibit negligible chromosome pairing because Basin wildrye contains neither $\mathbf{S t}$ nor $\mathbf{H}$ genomes.

Wilson (1963) recognizes 5 closely related taxa within Sitanion. Based on floral morphology, he considers S. longifolium J.G. Smith the most "primitive" member of the complex. It does not exhibit reduced sterile spikelets as in $S$. hordeoides Suksdorf; reduced sterile florets as in $S$. hystrix var. hystrix, $S$. hystrix var. californicum (J.G. Smith) F.D. Wilson, and S. jubatum J.G. Smith; or multi-cleft glumes as in S. hystrix var. hystrix or, to the extreme, S. jubatum. Sitanion hystrix var. hystrix, native to deserts and steppes, exhibits multicleft glumes, while var. californicum, native to montane sites, exhibits entire glumes. They may hybridize where their populations overlap. Some taxonomists have considered Sitanion jubatum $[=E$. multisetus] distinct (Hitchcock 1950, Wilson 1963, Barkworth et al. 1983), while others have considered it conspecific with $E$. elymoides (Holmgren and Holmgren 1977, Arnow 1993). Elymus elymoides and $E$. multisetus commonly hybridize where their ranges overlap in southeastern California and southern Nevada, though not appreciably in other regions (Wilson 1963). Because of the 
close relationship among these taxa, I consider the group a species complex (Sitanion hystrix sensu amplo) rather than taking a taxonomic "splitting" approach. However, this does not imply that the above mentioned entities are not associated with particular ecological niches or geographical distributions. An improved understanding of ecological adaptation within and between these entities will prove useful to successfully match plant materials with sites.

The fertile $S$. hanseni (Scribn.) J.G. Smith, derived from hybridization with blue wildrye, and the sterile Agropyron saxicola (Scribn. and Smith) Piper, derived from hybridization with bluebunch wheatgrass, were also included in Hitchcock's 1950 manual. Both $S$. hanseni (Stebbins et al. 1946) and A. saxicola (Dewey 1964) have been genetically characterized and their hybrid origins confirmed by comparison of artificial hybrids with natural specimens.

\section{Germination and Seedling Establishment}

Young and Evans (1977) attributed squirreltail's ability to colonize disturbed sites to rapid germination across a wide temperature range. However, $10^{\circ}(16 \mathrm{~h}) / 15^{\circ}(8 \mathrm{~h}), 10^{\circ} / 20^{\circ}$, and $15^{\circ} \mathrm{C}$ isothermal regimes were optimal for their material, collected in Nevada and northeastern California. Germination on the soil surface was $45 \%$ for a clay soil and $8 \%$ for a sandy loam, but seed germinated from deeper depths in the sandy loam.

Seeds used by Young and Evans (1977) did not exhibit afterripening, i.e., freshly harvested, fully mature seeds germinated as well as.seeds stored for 3 months. Seedlots tested by Allen et al. (1995), however, showed increased germination rate and percentage when stored at room temperature for 14 weeks. Cheatgrass (Bromus tectorum L.) seeds collected at Strawberry, Utah germinated faster with both continuous hydration and exposure to dehydration episodes, and exhibited less afterripening than squirreltail seed collected at the same site. Beckstead et al. (1995) found squirreltail and cheatgrass afterripened in dry storage over a period of 4 months, and cheatgrass had a greater afterripening requirement than squirreltail. For both species afterripening requirements of seeds from lower elevations were greater than from higher elevations. Both species emerged in the fall, but cheatgrass consistently emerged earlier.

Plant chemicals may have allelopathic effects on squirreltail, especially at germination and seedling stages. Radicle growth of squirreltail was almost completely suppressed by aqueous extracts of leaves and nonwoody stems of Utah juniper [Juniperus osteosperma (Torr.) Little] (Jameson 1968). Aqueous extracts of ponderosa pine ( $P$ inus ponderosa Lawson), piñon pine ( $P$. edulis Engelm.), Arizona fescue (Festuca arizonica Vasey), blue grama [Bouteloua gracilis (H.B.K.) Lag.], and squirreltail itself reduced radicle growth by $80 \%$ or greater compared to a water control. Aqueous leaf extracts of 4 Artemisia species and greasewood [Sarcobatus vermiculatus (Hook.) Torr.] inhibited germination of squirreltail (Reid 1964). Surface litter of big sagebrush (Artemisia tridentata Nutt.) reduced squirreltail germination from 18 to $11 \%$, but rabbitbrush litter [Chrysothamnus viscidiflorus (Hook.) Nutt.] had no effect (Schlatterer and Tisdale 1969). While seedling growth was inhibited for the first 4 weeks by sagebrush litter, this treatment was similar to the no-litter control by week 7 . This was attributed to either reduced growth inhibitors, increased nutrient availability, or both.
Seedlings of crested wheatgrass and especially squirreltail are more stressed when germinated in soil of dune interspaces between shrubs than in soil of coppice dunes beneath shrubs in the northern Great Basin (Wood et al. 1978). Vesicular horizons of dune interspaces are characterized by high silt content, low organic matter, poor aggregation, and low infiltration (Schlatterer and Hironaka 1972, Wood et al. 1978). These soils readily crust, inhibiting seedling emergence. Soil of coppice dunes beneath shrubs do not exhibit strong vesicular horizons, but boiling this soil in hydrogen peroxide to oxidize organic matter results in a poorly aggregated vesicular soil resembling interspace soil. Wood et al. (1978) postulated that rangeland soils may become vesicular when overgrazing removes herbaceous vegetation, leading to loss of soil organic matter and reduction of site potential. Deep-furrow seeding $(12.5 \mathrm{~cm})$ resulted in greater seedling emergence and establishment than drill $(2 \mathrm{~cm})$ or broadcast seedings for coppice soils, but drilling was superior for interspace soils (Wood et al. 1982). Squirreltail emergence compared favorably to crested wheatgrass and these workers recommended including squirreltail in seed mixtures. Hironaka and Sindelar (1973) noted frost heaving as a major factor contributing to winter seedling mortality on sites with little vegetative or litter cover.

\section{Secondary Succession}

Several studies have provided instruction as to the seral status of squirreltail. Poor range condition was associated with reduced frequency of needle-and-thread [Hesperostipa comata Trin. \& Rupr.) Barkw.] and increased frequency of squirreltail and big sagebrush in the big sagebrush/needle-and-thread habitat type of northern and eastern Nevada (Tueller and Blackburn 1974). Squirreltail was interpreted as being an increaser based on trend relationships across 23 sites. In contrast, squirreltail and big sagebrush increased and needle-and-thread decreased during 15 years of livestock exclusion in southeastern Idaho (Harniss and West 1973). Hironaka and Tisdale (1963) studied over 20 years of plant succession on an abandoned cultivated field in southern Idaho originally supporting sagebrush-grass vegetation. Netting was installed in 1938 to exclude blacktail jackrabbits (Lepus californicus) from a southern Idaho annual community of Russian thistle (Salsola kali L.) and mustards (Sisymbrium altissimum L., Descurainia spp.). An increase in cheatgrass in 1940 was followed by an increase in squirreltail, a temporary increase in mustards, and a decrease in Russian thistle in 1941. From 1948 to 1961 the community was a stable equilibrium of squirreltail and cheatgrass.

In light of previous research, Harniss and West (1973) considered squirreltail's climax status enigmatic. Young and Miller (1985) indicated it may be either a successional or a climax species. Squirreltail's seral status is probably related to genotype and site potential.

Redente et al. (1992) argued that nutrients are important organizing factors of the successional process in semiarid ecosystems. Above-ground biomass of the early-seral squirreltail was greater relative to the late-seral prairie junegrass [Koeleria pyramidata (Lam.) Beauv.] at higher levels of $\mathbf{N}$ and $\mathrm{P}$ compared to lower levels. Squirreltail displayed low tissue nutrient concentration and a high growth rate compared to junegrass' luxury consumption of nutrients and slow, sustainable growth rate.

Fire increased mineralized $\mathrm{N}$ in the organic fraction of soil beneath sagebrush canopies (Blank et al. 1994). Burned soil sup- 
ported greater growth of squirreltail and cheatgrass than unburned soil, but growth of Indian ricegrass [Achnatherum hymenoides (Roem. \& Schult.) Barkw.] and big sagebrush was reduced by burning. Squirreltail assimilated more $\mathrm{N}, \mathrm{P}$, and silica in burned than unburned soil. These researchers suggested that silica may substitute for carbon as a plant structural component. Whereas squirreltail produced 38 and $31 \%$ of cheatgrass shoot and root biomass, respectively, in unburned soil, squirreltail produced 56 and $58 \%$ of cheatgrass shoot and root biomass, respectively, in burned soil. This suggests that, once established, squirreltail's ability to compete with cheatgrass may actually be favored by fire.

Mineral $\mathrm{N}$ is often high after land disturbance, typical of "open nutrient cycling", and becomes successively organically bound as succession proceeds, typical of "closed nutrient cycling" (Odum 1969). In this process, as carbon becomes increasingly resistant to microbial decomposition, microbes serve as an $\mathrm{N}$ sink by reducing its availability to the plant. Rhizosphere-associated microbes influenced levels of plant-available $\mathrm{N}$ in a growth chamber study comparing squirreltail and bluebunch wheatgrass [Pseudoroegneria spicata (Pursh) A. Löve] (Frederick and Klein 1994). Immobilization and mineralization of organically bound $N$ were balanced when squirreltail was grown under high $\mathbf{N}$ conditions and inoculated with microbes previously isolated from the rhizosphere of this species. Likewise, immobilization and mineralization were balanced when bluebunch wheatgrass was grown under low $\mathrm{N}$ conditions and inoculated with microbes from its rhizosphere. Inoculation increased plant-available $\mathrm{N}$ with squirreltail under high $\mathrm{N}$ conditions (open nutrient cycling), while inoculation decreased plant-available $\mathrm{N}$ with bluebunch wheatgrass under low $\mathrm{N}$ conditions (closed nutrient cycling). Nitrogen balance was maintained neither when squirreltail was inoculated under low $\mathrm{N}$ conditions nor when bluebunch wheatgrass was inoculated under high $\mathrm{N}$ conditions. The specific microflora associated with the rhizosphere of a species may direct the rhizosphere's nutrient status to the species' own advantage, i.e., a symbiotic ecological relationship between the grass and its rhizosphere microbial population.

\section{Competition}

Squirreltail has shown potential as a competitor to medusahead wildrye [Taeniatherum caput-medusae (L.) Nevski] (Hironaka 1994). Squirreltail established on 2 of 3 medusahead wildrye ranges in southwestern Idaho when broadcast-seeded in September (Hironaka and Sindelar 1973). Seedlings germinated in fall and surviving seedlings developed rapidly. Medusahead wildrye litter minimized frost heaving, but squirreltail seedling survival decreased through the first growing season with annual competition. Without removal of existing vegetation, squirreltail's rapid seedling development suggested it would more successfully establish than bluebunch wheatgrass. Twenty-two squirreltail seedlings were established with $9,27,81,243$, and 729 medusahead wildrye seedlings per square foot (densities) in greenhouse containers (Hironaka and Sindelar 1975). Total individual plant biomass production at 85 days was about 3 times greater for medusahead wildrye than squirreltail at the lowest density of squirreltail and about 2 times greater at all other densities. Squirreltail root-to-shoot ratio increased from 0.51 at the lowest density to 1.05 at the highest density, while medusahead wildrye root-to-shoot ratio increased from 0.08 to 0.31 . Root biomass of individual squirreltail seedlings exceeded that of medusa- head wildrye seedlings at all densities, thus squirreltail appeared to be a good below-ground competitor with medusahead wildrye.

Squirreltail and medusahead wildrye were similar for relative growth rate (g/g/day) and its morphological component, leaf area ratio ( $\mathrm{m}^{2}$ leaf area $/ \mathrm{kg}$ biomass), but both were inferior to cheatgrass (Arredondo et al. 1998). Squirreltail and medusahead wildrye were also similar, but inferior to cheatgrass, for leaf dry matter, leaf area, specific leaf area $\left(\mathrm{m}^{2} / \mathrm{g}\right)$, relative root growth rate $(\mathrm{g} / \mathrm{g} /$ day), root dry matter, and root length. Specific root length $(\mathrm{m} / \mathrm{g})$ of squirreltail was smaller than medusahead wildrye or cheatgrass. Based strictly on these traits, squirreltail would be expected to compete more effectively against medusahead wildrye than cheatgrass.

In communities dominated by highly competitive perennials, squirreltail may be unable to establish without mechanical treatment. Thinning of the shrub component in a big sagebrush/Thurber needlegrass [Achnatherum thurberianum (Piper) Barkw.] community in southern Idaho increased squirreltail frequency 4-fold without increasing sandberg bluegrass (Poa secunda Presl.) or Thurber needlegrass (Tisdale et al. 1969). Despite squirreltail's abundance around the perimeter of a crested wheatgrass seeding in southeastern Idaho, obstruction by crested wheatgrass cover precluded wind dispersal of intact squirreltail spikes into the seeding (Marlette and Anderson 1986). They suggested deliberate removal of the crested wheatgrass stand and depletion of its seed bank would be required to reestablish a native community.

\section{Stress Response}

Squirreltail is considered a short-lived perennial (Hironaka and Fosberg 1979, Jensen et al. 1990). Its life-span is probably reduced by stress; 2 consecutive years of drought increased cover of dead squirreltail $77 \%$ near Reno, Nev. (Eckert and Spencer 1982). Summer regrowth of squirreltail after clipping was greater than for Indian ricegrass or needle-and-thread (Trlica and Cook 1971). In northern Utah squirreltail responded to fall rain, producing a second seed crop under favorable conditions (Coyne and Cook 1970).

Recovery was evaluated 1 year after a 19 July moderate-intensity controlled burn in an annual [Bromus tectorum, Sisymbrium altissimum, Descurainia pinnata (Walt.) Britt.]-dominated, squirreltail (quiescent stage; no green foliage) community in southeastern Oregon (Young and Miller 1985). Squirreltail shoot biomass increased $477 \%$, root biomass $50 \%$, spike biomass $1200 \%$, total shoot density $47 \%$, reproductive shoot density $664 \%$, and shoot/root ratio $302 \%$ compared to unburned controls. Crowns of squirreltail were not visibly damaged or reduced in size. Reduction in cheatgrass density was attributed to the fire's destruction of seed reserves and microsites for seedling establishment. In another eastern Oregon experiment, burning 15 May reduced squirreltail basal area $71 \%$ one year post-burn (Britton et al. 1990). Burning 15 June was least severe and 11 November was intermediate. Burning at $400^{\circ} \mathrm{C}$ was most detrimental to squirreltail in May and declined every month through September (Wright 1971). No trend was apparent with season for burning at $800^{\circ} \mathrm{C}$. Sandherg bluegrass was not damaged by fire in southwestern Idaho, while squirreltail, Thurber needlegrass, and needle-and-thread were increasingly susceptible to damage, respectively (Wright and Klemmedson 1965). In this study, squirreltail was damaged by $200^{\circ}$ and $400^{\circ} \mathrm{C}$ burns on 9 July (many seed shattered, foliage partially green), but not on 9 June (dough stage) 
or 18 August (most seed shattered, foliage still with some green coloration).

Wright (1971) attributes squirreltail's relative fire tolerance to a low density of dead plant material, leading to quick burns with minimal heat penetration to the crown. Squirrreltail has coarse stems with few leaves (Wright and Bailey 1982). In contrast, needle-and-thread accumulated $81 \%$ more litter than squirreltail, resulting in higher mortality after fire. Wright and Klemmedson (1965) speculated damage to squirreltail would be much more severe if leaves and inflorescences accumulated over several years in the absence of grazing or burning. Both squirreltail, found on clay sites, and needle-and-thread, found on sandy sites, in the vicinity of Boise, Ida., were most tolerant of 1-cm clipping at seed maturity (Wright 1967). Needle-and-thread was about 1 month earlier in maturity than squirreltail. Continued growth of needle-andthread following seed maturity was associated with a large amount of damage when clipped later in the season, while senescence of squirreltail allowed it to avoid serious damage.

Jirik and Bunting (1994) evaluated the effect of burning followed by clipping at $2 \mathrm{~cm}$ the subsequent year at 2 southern Idaho sites. When evaluated in the third year, squirreltail clipped at the boot stage had reduced biomass production and culm number compared to squirreltail clipped at the seed-ripe stage. Clipping at the boot stage the year following fire resulted in $26 \%$ mortality at the harsher Gem County site, though none at the milder Blaine County site. Squirreltail is readily consumed by livestock before spike emergence and after awn shattering, especially if fall rains produce new growth (Cook et al. 1954). Consequently, deferment of grazing the year after fire is important for squirreltail resurgence.

In a competitive cheatgrass environment, ability of a perennial grass to maintain root growth under cool temperatures has conferred an advantage for soil water extraction (Harris 1967, Harris and Wilson 1970). After 40 days at $5^{\circ} \mathrm{C}$, root weight of 2 squirreltail accessions was 36 and $45 \%$ of $20^{\circ} \mathrm{C}$ controls (Hironaka and Tisdale 1972). Total biomass of the 2 accessions at $5^{\circ} \mathrm{C}$ was 39 and $47 \%$ that at $20^{\circ} \mathrm{C}$. Squirreltail demonstrated continuous root growth throughout the 40-day period.

\section{Ecotypic Variation and Plant Material}

Distribution of members of the squirreltail complex ranges from the Pacific coast east to $90^{\circ} \mathrm{W}$ and from British Columbia and Alberta, Canada south to Baja California and Tamaulipas, Mexico (Wilson 1963). Flowering dates of 12 squirreltail accessions from 7 states varied across 2 months at a common location $64 \mathrm{~km}$ south of Flagstaff, Ariz. (Clary 1975). Phenological development was predicted by a climatic scale calculated from earliness of the growing season and average annual precipitation, but it was not associated with latitude. Accessions from warm and dry sites or cool and wet sites matured earlier than sites with moderate climates. Dry-matter production was greater for accessions from cool and wet or moderate sites than those from warm and dry sites (Clary 1975), which also exhibited narrower leaves (Clary 1979). Only negligible variation was found for water-use efficiency (Clary 1975), $\mathrm{CO}_{2}$-assimilation rate, stomatal density, thickness of abaxial epidermal cells and their walls plus cuticle, and cross-sectional area of the substomatal cavity and bulliform cells (Clary 1979). Shoot mitochondrial oxidation rates at 10 and $20^{\circ} \mathrm{C}$ increased along a gradient from low to high altitude (Klikoff 1966, Klikoff 1968, Hansen and Klikoff 1973).
Most squirreltail seed used for rangeland seedings comes from wildland harvests. For this reason, its availability is undependable, cost is high, and seed quality is potentially poor. Sand Hollow squirreltail germplasm (Gem County, Ida.) has been released for commercial seed production as a Selected Class of certified seed (natural track). It is adapted to medium-to-coarsetextured soils in southern Idaho and adjacent regions of Nevada, Oregon, and Utah (Jones et al. 1997). Although Sand Hollow was collected on a loamy coarse sand, it has performed well on silt loam and silty clay loam soils in Cache Cuunty, Utah. Sand Hollow was collected on a $35 \%$ west-facing slope at $830-\mathrm{m}$ elevation with estimated average annual precipitation of $28 \mathrm{~cm}$. Federal agencies, in cooperation with state agricultural experiment stations, may release additional material from Colorado, Idaho, Nevada, New Mexico, and Wyoming in the future.

\section{Future Prospects}

As an early-seral, short-lived perennial grass, squirreltail has potential for "assisted succession" in initiating reclamation of lands that have succumbed to weedy annual grass invasion and unnaturally high fire frequency (Hironaka 1994). Squirreltail would be seeded following wildfire or prescribed burns that have removed surface litter, reduced the annual seed bank, and increased soil nutrient availability. As squirreltuil becomes established and weedy annuals decline in dominance, difficult-toestablish long-lived native perennials could be reintroduced, most likely in subsequent post-burn seedings.

Squirreltail is well suited for this purpose because its fire tolerance allows it to survive sequential burns and its self-pollinating mode of reproduction allows it to produce seed despite sparse initial populations. Perennial plant material similar in biology to the weedy annuals, i.e., facultative fall germination, high growth rate under cool temperatures, root systems effective as foragers for soil nitrogen, efficient enzymology for nitrate assimilation, early reproductive maturity before moisture depletion, and high seed production early in the plant's life span, would have superior potential for competition and persistence. Only as experience is gained with newly available plant material can its effectiveness be determined. Future work should be directed at identifying important characteristics for adaptation, competitive ability, or seed production in future releases.

Seed demand should increase as utility of squirreltail for range rehabilitation is demonstrated and seed becomes lower in price and more consistently available. Seed price and availability should improve by increasing yields of harvestable seed. For example, plant material with tall, erect spikes that disarticulate intact may improve harvestable seed yield.

Tremendous genetic variation is present in squirreltail for heading date, seedling vigor, seed mass, seed production, and seed shattering characteristics. Matching plant material with site elevation, amount and distribution of precipitation, and soil texture will probably prove critical for successful rangeland seedings. Characteristics of squirreltail genotypes associated with seral status need to be identified. Then, early-seral material can be distinguished from later-seral material. Each may be used appropriately to assist succession to reclaim native ecosystems lost to decades of annual weed encroachment. 


\section{Literature Cited}

Allen, P.S., S.B. Debaene-Gill, and S.E. Meyer. 1995. Regulation of germination timing in facultatively fall-emerging grasses. p. 215-219. In: S.B. Monsen and S.G. Kitchen (eds.) Proc.: Ecology and Management of Annual Rangelands. USDA Forest Service INT-GTR313. Ogden, Ut.

Arnow, L.A. 1993. Gramineae A.L. Juss. p. 775-833. In: S.L. Welsh, N.D. Atwoox, S. Guodrich, and L.C. Higgins (eds.) A Utah Flora. 2nd ed. Brigham Young Univ., Provo, Ut.

Arredondo, J.T., T.A. Jones, and D.A. Johnson. 1998. Seedling growth of intermountain perennial and weedy annual grasses. J. Range Manage. 51 (in press).

Barkworth, M.A., D.R. Dewey, and R.J. Atkins. 1983. New generic concepts in the Triticeae of the Intermountain Region: Key and comments. Great Basin Natur. 43:561-572.

Beckstead, J., S.E. Meyer, and P.S. Allen. 1995. Effects of afterripening on cheatgrass (Bromus tectorum) and squirreltail (Elymus elymoides) germination. p. 165-172. In: B.A. Roundy, E.D. McArthur, J.S. Haley, and D.K. Mann (compilers) Proc.: Wildland Shrub and Arid Land Restoration Symposium. USDA Forest Service INT-GTR315. Ogden, Ut.

Blank, R.R., F. Allen, and J.A. Young. 1994. Growth and elemental content of several sagebrush-steppe species in unburned and post-wildfire soil and plant effects on soil attributes. Plant Soil 164:35-41.

Boyle, W.S. 1963. A controlled hybrid between Sitanion hystrix and Agropyron trachycaulum. Madroño 17:10-16.

Britton, C.M., G.R. McPherson, and F.A. Sneva. 1990. Effects of burning and clipping on five bunchgrasses in eastern Oregon. Great Basin Natur. 50:115-120.

Clary, W.P. 1975. Ecotypic adaptation in Sitanion hystrix. Ecol. 56:1407-1415.

Clary, W.P. 1979. Variation in leaf anatomy and $\mathrm{CO}_{2}$ assimilation in Sitanion hystrix ecotypes. Great Basin Natur. 39:427-432.

Cook, C.W., L.A. Stoddart, and L.E. Harris. 1954. The nutritive value of winter range plants in the Great Basin as determined with digestion trials with sheep. Utah Agr. Exp. Sta. Bull. 372.

Coyne, P.I. and C.W. Cook. 1970. Seasonal carbohydrate reserve cycles in eight desert range species. J. Range Manage. 23:438-444.

Dewey, D.R. 1964. Natural and synthetic hybrids of Agropyron spicatum X Sitanion hystrix . Bull. Torrey Bot. Club 91:396-405.

Dewey, D.R. 1967. Synthetic hybrids of Elymus canadensis X Sitanion hystrix. Bot. Gaz. 128:11-16.

Dewey, D.R. 1968. Synthetic hybrids of Agropyron dasystachyum X Elymus glaucus and Sitanion hystrix. Bot. Gaz. 129:309-315.

Dewey, D.R. 1969. Synthetic hybrids of Agropyron albicans X A. dasystachyum, Sitanion hystrix, and Elymus canadensis. Amer, J. Bot. $56: 664-670$.

Dewey, D.R. 1971. Synthetic hybrids of Hordeum bogdanii with Elymus canadensis and Silunion hystrix. Amer. J. Bot. 58:902-908.

Dewey, D.R. 1974. Cytogenetics of Elymus sibiricus and its hybrids with Agropyron tauri, Elymus canadensis, and Agropyron caninum. Bot. Gaz. 135:80-87.

Dewey, D.R. and A.H. Holmgren. 1962. Natural hybrids of Elymus cinereus X Sitanion hystrix Bull. Torrey Bot. Club 89:217-228.

Eckert, R.E., Jr. and J.S. Spencer. 1982. Basal-area growth and reproductive responses of Thurber needlegrass and squirreltail to weed control and nitrogen fertilization. J. Range Manage. 35:610-613.

Frederick, B.A. and D.A. Klein. 1994. Nitrogen effects on rhizosphere processes of range grasses from different successional seres. Plant Soil 161: 241-250.

Hansen, D.H. and L.G. Klikoff. 1973. Respiratory acclimation of Phleum alpinum and Sitanion hystrix. Amer. Midland Natur. 90:190-194.

Harniss, R.O. and N.E. West. 1973. Changes in Artemisia tridentata/Sitanion hystrix vegetation on the National Reactor Testing Station, southeastern Idaho, 1950-1965. Utah Acad. Proc. 50:10-16.

Harris, G.A. 1967. Some competitive relationships between Agropyron spicatum and Bromus tectorum. Ecol. Monogr. 37:89-111.
Harris, G.A. and A.M. Wilson. 1970. Competition for moisture among seedlings of annual and perennial grasses as influenced by root elongation at low temperature. Ecol. 51:530-534.

Hironaka, M. 1994. Medusahead: Natural successor to the cheatgrass type in the northem Great Basin. p. 89-91, In: S.B. Monsen and S.G. Kitchen (eds.) Proc.: Ecology and Management of Annual Rangelands. USDA Forest Service INT- GTR -313. Ogden, Utah.

Hironaka, M. and M.A. Fosberg. 1979. Non-forest habitat types of southern Idaho. Forest Wildl. and Range Exp. Sta., unnumbered Interim Rep., Univ. Idaho, Moscow.

Hironaka, M. and B.W. Sindelar. 1973. Reproductive success of squirreltail in medusahead infested ranges. J. Range Manage. 26:219-221.

Hironaka, M. and B.W. Sindelar. 1975. Growth characteristics of squirreltail seedlings in competition with medusahead. J. Range Manage. 28:283-285.

Hironaka, M. and E.W. Tisdale. 1963. Secondary succession in annual vegetation in southern Idaho. Ecology 44:810-812.

Hironaka, M. and E.W. Tisdale. 1972. Growth and development of Sitanion hystrix and Poa sandbergii. Desert Biome, U.S. International Biological Program RM 72-24.

Hitchcock, A.S. 1950. Manual of the grasses of the United States. 2nd ed. (rev. A. Chase). USDA Misc. Publ. No. 200. U.S. Gov. Print. Office. Washington, D.C.

Holmgren, A.H. and N.H. Holmgren. 1977. Poaceae. p. 175-464. In: A. Cronquist, A.H. Holmgren, N.H. Holmgren, J.L. Reveal, and P.K. Holmgren (eds.) Intermountain Flora. vol. 6. Columbia Univ. Press, New York.

Jameson, D.A. 1968. Species interactions of growth inhibitors in native plants of northern Arizona. USDA Forest Service Res. Note RM-113. Fort Collins, Colo.

Jensen, K.B., Y.F. Zhang, and D.R. Dewey. 1990. Mode of pollination of perennial species of the Triticeae in relation to genomically defined genera. Can. J. Plant Sci. 70:215-225.

Jones, T.A., D.C. Nielson, D.G. Ogle, D.A. Johnson, and S.A. Young. 1998. Registration of Sand Hollow squirreltail. Crop Sci. 38:326-331.

Jirik, W.J. and S.C. Bunting. 1994. Post-fire defoliation response of Agropyron spicatum and Sitanion hystrix. Int. J. Wildl. Fire 4:77-82,

Klikoff, L.G. 1966. Temperature dependence of the oxidative rates of mitochondria in Danthonia intermedia, Penstemon davidsonii and Sitanion hystrix. Nature 212:529-530.

Klikoff, L.G. 1968. Temperature dependence of mitochondrial oxidative rates of several plant species of the Sierra Nevada. Bot. Gaz. 129:227-230.

Marlette, G.M. and J.E. Anderson. 1986. Seed banks and propagule dispersal in crested wheatgrass stands. J. Appl. Ecol. 23:161-175.

Odum, E.P. 1969. The strategy of ecosystem development. Sci. $164: 262-270$.

Redente, E.F., J.E. Fricdlander, and T. McLendon. 1992. Response of early and late semiarid seral species to nitrogen and phosphorus gradients. Plant Soil 140:127-135.

Reid, A. 1964. Growth inhibitors in shrub species in Wyoming. Bull. Ecol. Soc. Amer. 45:94.

Schlatterer, E.F. and M. Hironaka. 1972. Some factors influencing tolerance to moisture stress of three range grasses. J. Range Manage. 25:364-367.

Schlatterer, E.F. and E.W. Tisdale. 1969. Effects of litter of Artemisia, Chrysothamnus, and Tortula on germination and growth of three perennial grasses. Ecol. 50:869-873.

Stebbins, G.L. and A. Vaarama. 1954. Artificial and natural hybrids in the Gramineae, tribe Hordeae. VII. Hybrids and allopolyploids between Elymus glaucus and Sitanion spp. Genetics 39:378-395.

Stebbins, G.L., Jr., J.I. Valencia, and R.M. Valencia. 1946. Artificial and natural hybrids in the Gramineae, tribe Hordeae. I. Elymus, Sitanion, and Agropyron. Amer. J. Bot. 33:338-351.

Tisdale, E.W., M. Hironaka, and M.A. Fosberg. 1969. The sagebrush region in Idaho-a problem in range resource management. Ida. Agr. Exp. Sta. Bull. 512.

Trlica, M.J., Jr. and C.W. Cook. 1971. Defoliation effects on carbohydrate reserves of desert species. J. Range Manage. 24:418-425. 
Tueller, P.T. and W.H. Blackburn. 1974. Condition and trend of the big sagebrush/needleandthread habitat type in Nevada. J. Range Manage. 27:36-40.

Wang, R.R-C., R. von Bothmer, J. Dvorak, G. Fedak, I. LindeLaursen, and M. Muramatsu. 1996. Genome symbols in the Triticeae (Poaceae). p. 29 -34. In: R.R -C. Wang, K.B. Jensen, and C. Jaussi (eds.) Proc. 2nd Int. Triticeae Symp. Logan, Ut.

Wilson, F.D. 1963. Revision of Sitanion (Triticeae, Gramineae). Brittonia 15:303-323.

Wood, M.K., W.H. Blackburn, R.E. Eckert, Jr., and F.F. Peterson. 1978. Interrelations of the physical properties of coppice dune and vesicular dune interspace soils with grass seedling emergence. J. Range Manage. 31:189-192.

Wood, M.K., R.E. Eckert, Jr., W.H. Blackburn, and F.F. Peterson. 1982. Influence of crusting soil surfaces on emergence and establishment of crested wheatgrass, squirreltail, Thurber needlegrass, and fourwing saltbush. J. Range Manage. 35:282-287.
Wright, H.A. 1967. Contrasting responses of squirreltail and needleandthread to herbage removal. J. Range Manage. 20:398-400.

Wright, H.A. 1971. Why squirreltail is more tolerant to burning than needle-and-thread. J. Range Manage. 24:277-284.

Wright, H.A. and A.W. Bailey. 1982. Fire ecology: United States and southern Canada. John Wiley \& Sons, New York.

Wright, H.A. and J.O. Klemmedson. 1965. Effect of fire on bunchgrasses of the sagebrush grass region in southern Idaho. Fcol. $46: 680-688$.

Young, J.A. and R.A. Evans. 1977. Squirreltail seed germination. J. Range Manage. 30:33-36.

Young, R.P. and R.F. Miller. 1985. Response of Sitanion hystrix (Nutt.) J.G. to prescribed burning. Amer. Midland Natur. 113:182-187. 